\begin{tabular}{l} 
MISCELLANEA \\
GEOGRAPHICA \\
\hline
\end{tabular}

Vol. 132008

pp. 33-49

\author{
Michał Osowiec \\ University of Warsaw - Faculty of Geography and Regional Studies \\ 00-927 Warsaw, Krakowskie Przedmieście 30 \\ e-mail: mosowiec@uw.edu.pl
}

\title{
FUNCTIONING OF HYDROGENIC LANDSCAPES THE UPPER WŁODAWKA RIVER CATCHMENT BASIN
}

\begin{abstract}
In the dissertation, I analysed two aspects of the Polesie Lubelskie landscape. The first is the historical aspect - changes in the landscape in the $19^{\text {th }}$ and $20^{\text {th }}$ centuries. In evaluating such changes I relied on the existing maps and relevant literature. The second aspect is the contemporary functioning of the hydrogenic landscape, changes over the course of the year or seasonal changes. This is to allow an assessment of contemporary changes in the environment.

The fieldwork focuses on three components or three factors of the environment: water, soil and vegetation. The water factor is analysed by measuring oscillation of the ground water table as well as the chemical content of river and ground waters. The soil component is examined to determine distribution of various soil types in the study area. Vegetation is analysed by spatial distribution of floral assemblages. I am researching chemical features such as the levels of $\mathrm{Ca}, \mathrm{HCO}_{3}^{-}, \mathrm{Mg}, \mathrm{N}, \mathrm{P} \mathrm{K}, \mathrm{Fe}, \mathrm{S}, \mathrm{Cl}, \mathrm{Si}$ and $\mathrm{pH}$.
\end{abstract}

Key words: functioning of landscapes, hydrogenic landscapes, Polesie Lubelskie, marl peat bogs

Landscape functioning is to be comprehended as an exchange of matter, energy and information with the environment and proper changes which occur inside the geocomplex as the result of its influence (Richling 1992). Differently, functioning is described as a change of conditions of the geocomplex or transformation. Not always, however, these terms are synonymous. This refers to cyclical as well as evolutionary changes. The main environmental functioning processes include denudation, air mass transfer, migration of living organisms, migration of chemical 
elements and surface and underground runoff. The fundamental task in explaining functioning is recognition of the spatial structure and relationship between components of a given area.

Landscape functioning was examined by means of an analysis of selected elements, i.e. hydrologic relationships, soil and vegetation. Fluctuations of the surface of underground waters and spatial and seasonal diversity of the chemical characteristics of water in relationship to the substratum and topographic features of the area were analysed. The influence of hydrologic conditions on soil processes and diversity of plant communities were also examined.

The method applied in this paper methodologically approximates analyses of partial landscapes and is based on the reduction of research issues to selected dominant components and processes. The geosystem is divided into several subsystems, singled out on the basis of diverse components related to different forms of matter (Richling, Solon 2002).

Hydrogenic landscape is the subject of research. It is understood as a segment of the natural environment in which water is the main carrier of matter and energy. Therefore, it is a landscape in which the water factor decides about the course of the main processes and the dynamics of the natural environment. In geochemistry such kinds of geocomplexes are described as superaquatic landscapes (Perelman 1971).

Hydrogenic landscapes are an important element of the structure of the natural environment, create landscapes, play a significant role in water circulation. Thanks to significant autarchic and homeostatic characteristics, water-peat bog ecosystems stabilize landscapes and their biotopic and biocenotic diversity (Radwan, Chmielewski 1997). Analyses of hydrogenic landscapes were carried out because of their limited examination both in aspect of their structure as well as functioning and lack of an unambiguous classification system of such areas.

The paper had a double objective, i.e. cognitive as well methodical and practical. In the cognitive aspect, the objective is identification of selected aspects of functioning of the landscape. This was done by:

- identification of the structure of the examined segment of hydrogenic landscape,

- analysis of changes in landscape in the $19^{\text {th }}$ and $20^{\text {th }}$ centuries on the basis of maps and historic documents,

- determining the level of concentration of the main water ions in individual functional units and their seasonal changes, 
- characteristics of the seasonal dynamics of the fundamental hydrogeochemical parameters,

- analysis of relationships between landscape functioning parameters.

Practical objectives comprise determination of the degree of anthropressure and an analysis of the possibility of using research for the purpose of protecting and managing the environment as well as identifying the susceptibility of the hydrogenic landscape to transformation.

Identification and realization of the research objectives were carried out on the basis of characteristics of the examined landscapes. It was assumed that in majority of the functioning hydrogenic landscapes vertical water movement dominates. This results in an analogical transfer of matter and energy. Therefore, analyses of the functioning of hydrogenic landscapes were made by identification of the aforementioned landscape characteristics and their variability under the influence of changes taking place in it.

\section{SUBJECT OF RESEARCH}

Due to the role of water circulation, the catchment basin was identified as the fundamental unit. A segment of the Poleski National Park (the Bubnów and Staw nature reserves), enclosed by the border of the Włodawka River upper catchment basin (Bubnowo stream), is the research subject. The area being examined is almost 6 000ha. According to Kondracki's physical-geographic classification (2000), this area is located in the southern part of the Polesie Lubelskie Macroregion (Western Polesie). The Włodawka River upper catchment basin is located in the southern part of the mezoregion of the Łęczyńsko-Włodawskie Lake District. For the most part, the region being examined includes a sequence of three basins with gradually increasing area joined by a stream, i.e. Serniawy Basin, Bagno Staw and Bagno Bubnów. Most of this area is covered by lowland bogs with elements of carbonaceous peat bogs with very significant natural values and relatively small degree of transformation. Beyond this sequence is Zastawie Terrace.

Polesie is a geographic region located in the lowland eastern part of Europe. The Polesie region is situated on the territory of several countries, i.e. Belarus, Ukraine and Russia. The most westward part 
of the region, called Polesie Lubelskie, belongs to Poland. This area is characterised by unique values of the natural environment, not to be found on the international scale. Thus, in the year 2000, part of this region was given the status of the International Biosphere Reserve "Polesie Zachodnie".

Polesie Lubelskie is the most swampy region in Poland's old glacial landscape, where hydrogenic biotopes comprise over $40 \%$ of the area. Natural water-peat bog ecosystems are present here. The landscapes of western Polesie Zachodniego are located on the most south-western segment with forest-tundra characteristics (Fijałkowski 1960).

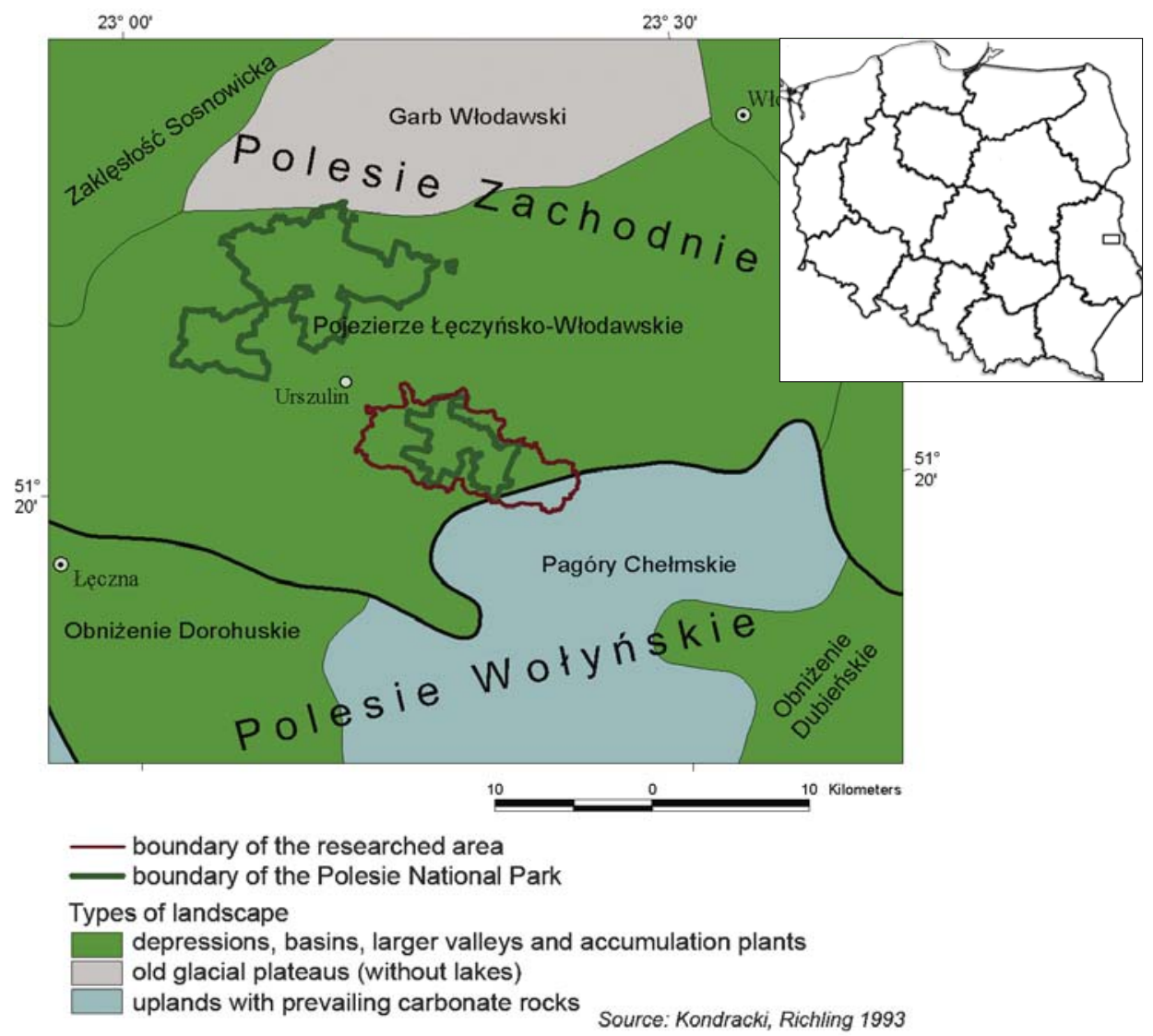

Fig. 1. Location of the fieldwork against the background physico-geographical regionalization of Poland 
The choice of research grounds representative for the hydrogenic landscapes of Polesie Lubelskie was made because of its typical Polesie characteristics which include a peat bog catchment basin. An important selection criterion was also the need to find an area which, to a limited extent, was transformed by man. This would allow to present the natural structural-functional dependencies.

\section{THE METHODS}

Research on landscape changes in 1839-2002 was carried out using maps from different time periods, historical documents and bibliographies comprising changes of particular components of the natural environment (Radwan et al. 2002 a, b, c; Radwan 2003).

Materials elaborated for the nature conservation plan of the Polesie National Park, on which the nature monograph on the Poleskie National Park was developed, were also used (Radwan 2002). Own observations were also carried out. The following maps were used for an analysis of the use of the area:

- Topographic Map of the Kingdom of Poland, 1:126 000, Warszawa 1839-1843,

- Novaya Topographitcheskaya Karta Zapadnoy Rosyi, 1:84 000, Petersburg 1913,

- Elementary map, the Military Institute of Geography 1932-1933, Sheet Włodawa,

- Military Topographic Map, 1:100 000, 1994, Sheets Włodawa and Sawin.

The above mentioned maps were reduced to the scale 1:100 000 and calibrated in an arrangement of coordinates 1965 by using programs of the ArcView and ArcInfo software. With the help of the ArcView program, the area of marshes and forests. Stream lengths were calculated as well. Next, the percentage share of the analysed area on each of the maps was identified. The present state was evaluated on the basis of a tourist map of the Polesie National Park and the author's own familiarity with the area.

Field research. Within the framework of the chosen area, observation of the fluctuation of ground water surface and water $\mathrm{pH}$ were carried out. Research was conducted between October 2000 and September 2002 in eight measuring series, each characterizing particular seasons. Dur- 
ing the 2001/2002 season, water samples from 30 stations were taken in order to determine the chemical composition and from several other stations in which analysis was made only once. Stations representative of the selected geocomplexes were selected for water sample intake.

Soil and vegetation mapping was made. Fifty six stations were described, including 13 open pits, 39 drilling holes and 4 exposures. Fifty soil samples were taken from twenty six stations. For the most part, they were samples of organic material used to mark selected chemical characteristics.

Laboratory research. In the laboratory, fundamental physical and chemical characteristics of soil and selected chemical characteristics of water were determined. The soil ash content and organic substance content, $\mathrm{pH}$, the chemical composition of the ash content and the overall content of selected components in $\mathrm{Fe}_{2} \mathrm{O}_{3}, \mathrm{Al}_{2} \mathrm{O}_{3}, \mathrm{CaO}$ and $\mathrm{MgO}, \mathrm{SiO}_{2}$, total nitrogen $\mathrm{N}$, phosphorous $\mathrm{P}$, potassium $\mathrm{K}$ were all marked in the soil samples.

An analysis of the chemical components of water were made by using the atomic absorption spectrophotometer (ICP). The content of calcium $\mathrm{Ca}$, magnesium $\mathrm{Mg}$, iron $\mathrm{Fe}$, sodium $\mathrm{Na}$, potassium $\mathrm{K}$, phosphorous $\mathrm{P}$, sulphur $\mathrm{S}$, chlorine $\mathrm{Cl}$ and silicon $\mathrm{Si}$ was measured. Other methods were used to determine the $\mathrm{pH}$, content of nitrates $\mathrm{NO}_{3}$, nitrites $\mathrm{NO}_{2}^{-}$, carbon trioxide $\mathrm{CO}_{3}{ }^{2-}$ and hydrogen carbonate $\mathrm{HCO}_{3}^{-}$. Data obtained on the basis of analyses of the chemical characteristics of waters were presented in concentration units per volume $(\mathrm{mg} / \mathrm{L})$. The Szczukariew-Prikłoński method was used to.

\section{RESULTS AND CONCLUSIONS}

The rhythm of fluctuation of the surface of ground waters indicates strong interaction between them. Between autumn and April there was a noticeable increase in the level of ground and surface waters. This is followed by a decrease in their level to the summer-autumn minimum. Depending on the seasonal meteorological conditions, periodically, following intense rainfall, high levels of water were observed during the summer-autumn period.

Depositional basins standing out in the examined area are characterised by small and slow changes in the depth of water surfaces, maximum 10-30 centimetres. However, transitional zones between 
lithogenic and hydrogenic landscapes with transitional-depositional geochemical characteristics, the lithohydrogenic landscapes, are characterised by large fluctuations of ground waters.

During the winter-spring period in the near-surface zone, i.e. that of active water exchange, it gets on to standardization of chemical parameters. In the summer-autumn period, segmentation of the catchment area into basins takes place, i.e. into depositional landscapes and uplifts of eluvial and eluvial-depositional geochemical characteristics which separate them.

The vertical variability of the chemical composition of ground waters depends on the chemical characteristics of the water-bearing layer, the impermeable substratum and the course of hydrogeochemical processes occurring in the environment. At the same time, the process of intensity differs, depending on the depth. Here, decisive are the hydrodynamic and hydrogeological conditions, temperature, pressure and the oxidizing-reduction conditions. Under the influence of the above mentioned factors and the variability of occurrence of gases, together with the depth, increases mineralization of water and the relations between the concentration of macro and micro components. Changes in the chemistry are gradual, seldom abrupt. They take place on the borderline of geological layers of differing permeability which may be exemplified by the borderline between peat bogs and marl or sand-loam deposits and marls.

It was noted that in river waters, fluctuation of the concentration of the analyzed ions is much smaller than in ground waters. The reason for this is the process of integration and reduction to the hydrogeochemical background of diluted substances flowing with river waters.

Waters of the examined area are dominated by double ions of hydrogen carbonate-calcium $\mathrm{HCO}_{3}{ }^{-}-\mathrm{Ca}^{2+}$. This testifies to the significant stability of the ions both of surface waters as well as ground waters. Triple ion waters of hydrogen carbonate-sulphide-calcium $\mathrm{HCO}_{3}-\mathrm{SO}_{4}{ }^{2-}$ $-\mathrm{Ca}^{2+}$ are characteristic to zones where Quaternary waters mix with Cretaceous waters. Above all, this refers to the zone of the KulczynWólka Tarnowska fault. The existence of waters enriched by chloride ions $\mathrm{HCO}_{3}-\mathrm{Cl}^{-}-\mathrm{Ca}^{2+}$ is the result of anthropogenic pollution. In the zones of contact between ground and surface waters there is a seasonal change in water classification. The contact between ground and underground waters has been confirmed from a hydrogeological as well as hydrochemical perspective. 
The significant variability of the chemical composition of water is related to the seasonal mixing occurring between functional basins. These processes take place within geochemical barriers separating particular peat bog basins as well as in transitional zones between limited sedimentation basins and mineral uplifts which separate them.

Waters from transitional zones are characterised by a large variability of sodium and potassium cations and the presence of sulphate anions. The spatial variability of the chemical characteristics of water is presented in fig. 2 .

On the edges of peat bog basin, in the spring, waters of the hydrogen carbonate-calcium-sodium $\mathrm{HCO}_{3}-\mathrm{Ca}^{2+}-\mathrm{Na}^{2+}$ class were noted. Enriched by a sodium ion, it is related to the existing reduction conditions. Four ion waters are represented by hydrogen carbonate-chloride-calcium-sodium $\mathrm{HCO}_{3}-\mathrm{Cl}^{-}-\mathrm{Ca}^{2+}-\mathrm{Na}^{2+}$. They are present in marl deposits composing the low mineral level in the Serniawy basin. Enriched in $\mathrm{Cl}^{-}$and $\mathrm{SO}_{4}{ }^{2-}$ anions, waters of the hydrogen carbonate-sulphidecalcium $\mathrm{HCO}_{3}-\mathrm{SO}_{4}{ }^{2-}-\mathrm{Ca}^{2+}$ class were found at the water source of the Cretaceous level.

In the marsh and peat bog areas, where soil processes are the most intense, maximum concentration of mineral substances occurs in the sub-soil zone. As a result of rising of the water surface level there also occurs stronger surface water evaporation and transpiration which also augments mineralization. In consequence, this leads to the enrichment of water by sodium at the expense of calcium and magnesium. The decrease of mineralization is related to the dilution of ground waters by surface waters. Together with an increase of mineralization in ground waters increases the calcium (Ca) content and at the same time, the sodium content $(\mathrm{Na})$ decreases. This regularity stems from intensification of the ion exchange which is related to long term cooperation of ground waters with rock deposits in which calcium $\mathrm{Ca}^{2+}$ dominates in the ion complex. The river water variability index is related to their flow through diverse substrata and varied alimentation. Alimentation significantly influences the character of the chemical background of ground waters. In conditions of smaller retention, more decomposed peat bog grows because it is located above water surface, in conditions favourable to decomposition. In the next stage of transformation, peat undergoes mineralization and in the vicinity of peat swamp basin, silting. Strongly decomposed and silted peat mass is submerged during flooding. Thus, conditions for growth of rush vegetation are created. 


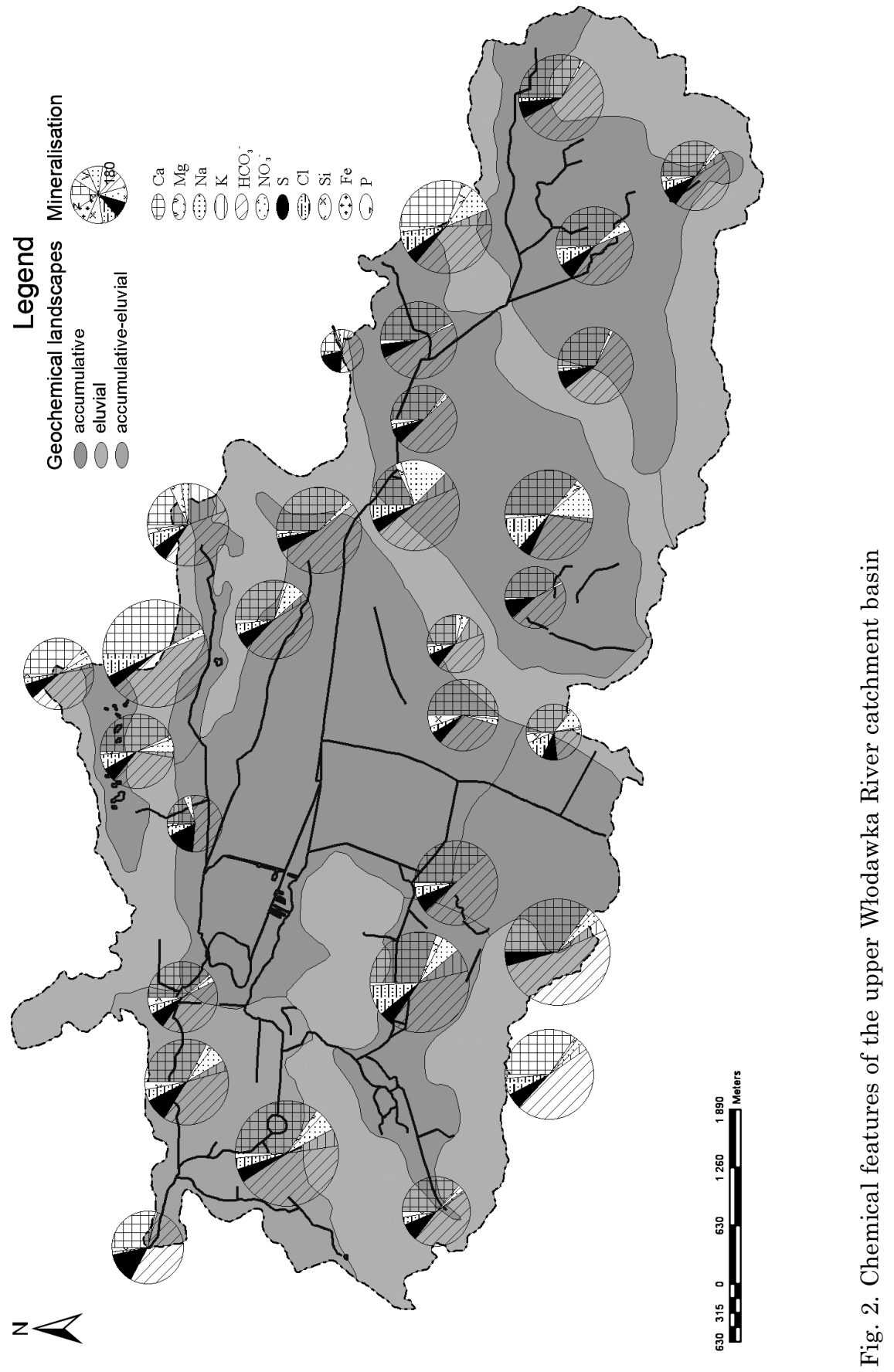


Retention capabilities influence the surface and ground water flow, fluctuation of water level, shape decomposition and silting, decide about changes in plant association in the direction of a sedge-mszystej meadow or rushes. The greater the retention, the smaller the flow and lesser fluctuation. Flow of waters from leakage in places of contact with mineral areas results in the complex character of peat drain. In consequence of water movement, their acidification increases which leads to floral impoverishment which has been observed in the northwestern part of the catchment basin.

Small retention potential intensifies the fluctuation of the ground water level which leads to the growth of vegetation needing deep inundation. Increase in fluctuation of the water surface eliminates high sedge associations, deeply rooted and favours meadow, turf vegetation. Reduction of the inflow decreases the scope of fluctuation of the water level. Then, at the same time, there is mszystej and high sedge layer.

Lowering of the water level as a result of melioration leads to the substitution of telmathic by terresthic brushwood and forest associations. Also, this process leads to overdesiccation and changes in the floral characteristics of meadows. Sedge- moss associations were replaced by sedge associations. As a result of canalization (concentration and flow improvement), at the same time, with lack of sufficient slopes allowing for dehydration, develops enrichment into a well formed moss layer, assemblage of the Magnocaricion order .

On edges of the moss basins, within areas of sandy lake-flooding plains, acid reaction waters stagnate (4-5).

This leads to transformation of cyperaceous lowland bogs or carbonaceous into transitional low sedge moors from the ScheuchzerioCaricetea Nigrae class. Heathlands were also observed throughout the mentioned areas.

The catchment basin of the upper Włodawka River, despite a significant influence of anthropressure, is characterised by a greater degree of naturalness than other areas of the Polesie region. Among others, this is proven by a different composition of ground mineral waters of particular alimentation basins. In these waters, apart from farm wells, there was not a higher concentration of chlorine, phosphorous and potassium. Large biotic diversity, manifested by the diversity of natural plant associations and a significant share of rare species, confirms this opinion. Uncontrolled fires of Bubnów and Staw peat bog 
complexes which repeatedly occurred until the creation of the Polesie National Park led to greater biotic diversity. This is also confirmed by analysis of changes in the $19^{\text {th }}$ and $20^{\text {th }}$ centuries in the background of changes of the Łęczyńsko-Włodawskie Grand Lakes region. This is the reason for greater usefulness of the testing grounds as the subject of research on hydrogenic landscape.

Despite the partially disturbed, by man's interference, dynamics of the system, the hydrogenic landscapes of the upper Włodawka River catchment basin, to a large degree, meet the objectives of their functions:

- creating a chemical element balance,

- cumulating nutritive components and water purification related to identification and substance fixation in plants due to great filtration characteristics of biogenic deposit sedimentation in the form of peat,

- conservation of biodiversity, the last refuge of rare plant species and entire biocenosis,

- balance of landscapes and their biotope and biocenotic diversity thanks to significant autarchic and homeostatic characteristics of water-peat bog ecosystems.

Catchment basins function in two spatial and time ranges:

- regional - supply of water, gaseous and solid substances from the atmosphere and ground waters of relatively homogenous chemical characteristics,

- local - comprising spa1tial diversity of the landscape in a given catchment basin,

- vertical - relationship between landscape subsystems,

- temporal - by momentary, twenty-four hour, seasonal, annual and long term reproducible occurrence of complex processes.

Lithohydrogenic areas, where there is transport of mineral elements, microorganisms and suspensions and removal of these substances from subsystem solution (basin) have decisive significance to the level of water migration. Lithohydrgenic landscapes are the most unstable, i.e. weak links of the landscape system, are most endangered by anthropogenic transformation.

Under natural conditions, the Polesie landscape functions in the chamber-overflow system. Sedimentation of mineral and organic substances migrating with ground and rain waters occurs in the basins. Biotope trophism is decisive on the biological productivity of particular chambers. 
Lithogenic landscapes separating depressions (chambers) serve the role of membranes. As entrance to the system serve transit-superaquatic landscapes on one side of the catchment area. The other side of the membrane (positioned as watersheds) are the exists. Tide between the basins is possible with total water saturation. The main processes taking place in the examined catchment basin are shown in the model in fig. 3 .

The examined area is characterised by significant individuality. This stems from a specific structural arrangement and geographic location. This area is located in a zone in which the Atlantic and continental climates superimpose on each other. This results in, among others, non-harmonic plant succession. The specificity of the upper Włodawka River catchment basin is also the result of presence of carbonate peat bogs. The functioning of the examined landscapes is characterised by slow exchange of water and diversity of its physical and chemical characteristics. Lowland bog landscapes in the examined Polesie area are characterised by limited water inflow. This is the result of small sloping of the land, limited contact between basins and large retention which is derived from the basin shape (depth and extensiveness). The horizontal movement of water is only visible in the form of filterability through peat bog mass. With a balanced supply of ground waters and atmospheric rainfall, value of retention is significant. In the examined area, evaporation is greater than rainfall therefore ground supply is an important element of the water balance. It amounts to almost half of all the supplied waters. On the regional scale, this area is located in transit between the Lublin and Wołyn Upland and the Warsaw Basin.

The stability of the analyzed landscape system is being disturbed because of human interference. Changes caused by man's activity significantly reduced the retention capability of hydrogenic landscapes and therefore, they require rational protective measures without which they remain endangered by unfavourable transformations.

Vertical water movement dominates in the hydrogenic landscapes of the upper Włodawka catchment basin as well as in the entire area of Polesie Lubelskie. The following factors are decisive:

- shaping of the landscape surface,

- dominating role of precipitation and evaporation in reference to inflow and outflow,

- supply of Cretaceous waters. 


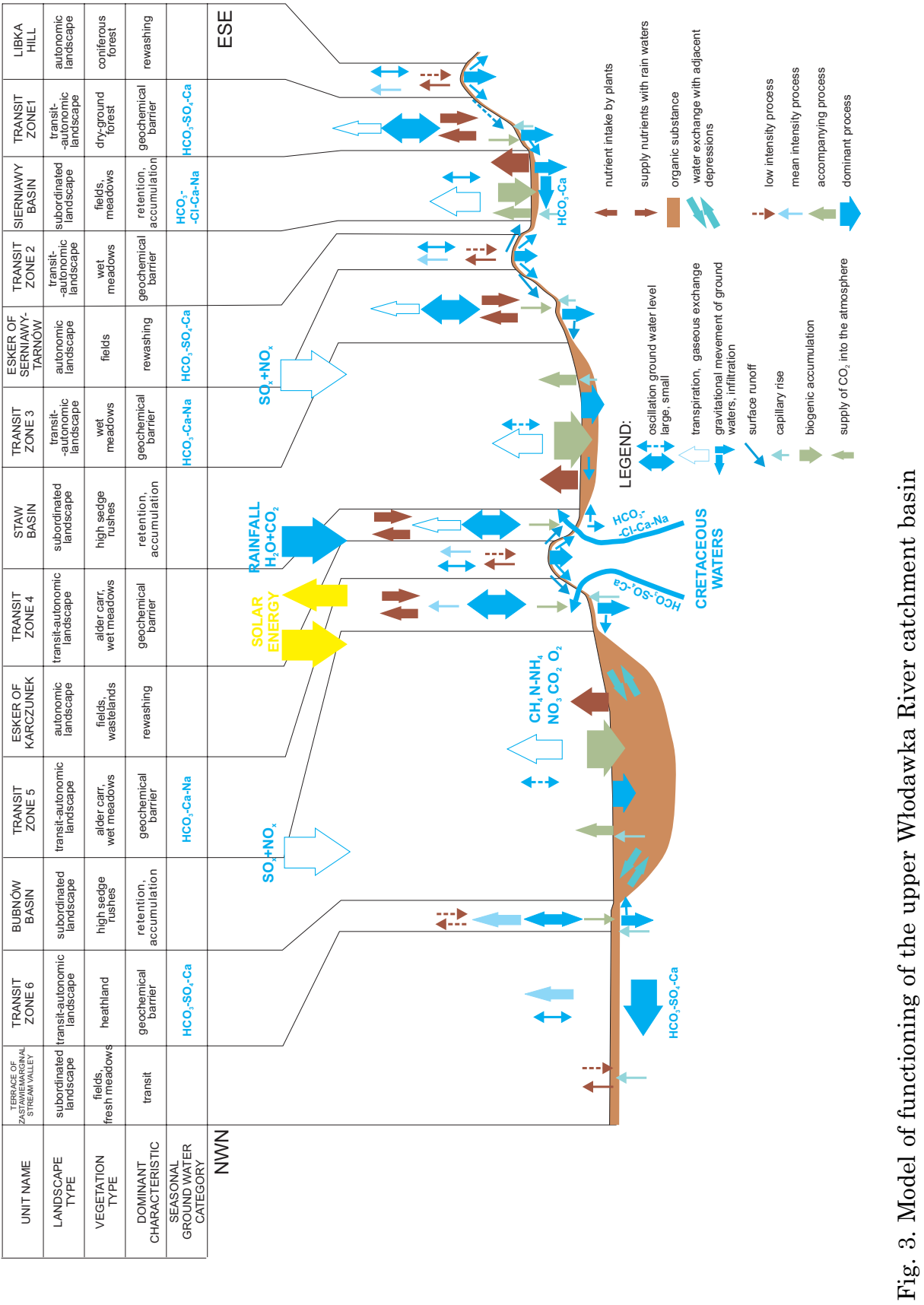


Foremost, diversity of plant communities in the Polesie landscape is the result of changes in water relations in peat bog development and not a simple plan of succession. Changes in plant cover are determined, above all, by:

- increase in ground water intake for municipal and industrial needs from confined aquifer levels,

- drained ground subsidence following removal of hydraulic damming leading to intensification of the rotting process.

The main processes taking place in the examined landscapes include humification (in conditions of continuous irrigation) and mineralization of organic substances. Long term desiccation and aeration of peat bog generates mineralization, that is rotting ("flameless burning") and disappearance of peat bog beds. Lowering the ground water level led to peat bog drainage, rotting and accelerated mineralization of organic substances. As a result of these processes the peat bog area was lowered and peat in the sub-soil layer demonstrates evident concentration (increase of volume density, Wicik 1997).

Due to the richness of resources and water phenomena, great biotope and species diversity and the dominating role in transfer of matter, energy and biological information, hydrogenic landscapes play a key role in conservation and management of ecological relations on the beyond-the-region scale. Hydrogenic landscapes are a dynamic element of the water retention system which cumulates biofile elements. They play an unusually significant role in water circulation because these areas are an important water reservoir in the landscape, regulate outflow, its size and schedule. Because of the general function of the water factor in the landscape and in particular in hydrogenic areas, the element balance is created under their influence.

Suggestions for conservation activities in the examined area:

- enlargement of the park borders by hydrogenic landscapes bordering on the Bubnów and Staw wilderness depression and the Serniawy basin. This would allow to increase the system's retention capacity and its protection against pollutants,

- periodic limiting of water outflow from retention pools for the purpose of slowing down outflow from the catchment basin and creating water storage for the period of low water level and preventing rotting processes,

- popularization of ecological forms of agriculture management to decrease biogenic supply to peat bog basins, 
- mechanical removal of trees and shrubs from area originally occupied by rush plants,

- moving of peat bog to remove expansive alien species from overgrown meadows following implementation of strict conservation,

- controlled burning of dry plant mass from communities transformed during winter on frozen grounds.

\section{SUMMARY}

Assumptions regarding the superiority of functioning of vertical landscape as well as the dominant role of water, soil and plants have proven themselves. The physical-geographic (geoecological) and geochemical research methods applied here have shown to be sufficient for the realization of the assumed research objectives.

While examining the natural environment one may observe mutual penetration of structure and function. Verification of landscape functioning may be carried out in its various aspects. The presented research results include the most important components of the landscape system from a geoecologist's (geographer's) perspective. It seems important to continue work on creating a fixed network for monitoring function parameters with frequent measuring, especially physicalchemical parameters and dynamics of water circulation, as well as changes in the physical, chemical and biological characteristics of soil and directions of plant succession. The existing network of research on the condition of ground waters should be supplemented by a piezometer network installed in peat bog basin and transit-sedimentation lithohydrogenic landscapes. There is a need for stationary research on the composition of precipitation, characteristics and role of snow cover as well as short term examination of the system's reaction to, for example, torrential rains, repeated in short time spans. Without recognition of detailed parameters for the functioning of a catchment basin and its variability, it is impossible to carry out work on conservation of the natural state which is so important in ecosystem landscapes or its renaturization.

Application of specific criteria of delimitation of the structuralfunctional landscape units depends on the specificity of the examined landscape as well as the objective and scale of the study. Different types of landscapes are shaped under the influence of various processes 
and influence the component selection. Objectives of the study force application of an applicable method for selecting units. In a decisive manner the scale of the study determines its execution. The proposed method for delimitating landscape units proved to be correct for landscapes outnumbering the hydrogenic ones, especially in reference to an area which is not too large.

It is possible to hope that this research will be used for further detailed analyses and will be helpful in carrying out conservation activities in the upper Włodawka River catchment basin which, partially, is under the protection of the Polesie National Park as well as the method of conducting renaturization projects or determining the directions of spatial management of communities. Th multi-level data base executed as part of this elaboration could be used in a project on detailed monitoring of the catchment basin. The proposed research method seems to be correct and it also is possible to apply it in other analogical hydrogenic landscapes of the Earth, especially in the moderate zone.

In consequence of the conservation and renaturization projects being conducted in the upper Włodawka River catchment basin one may assume that the condition of the examined landscapes and their functioning will not be particularly changed, remaining close to the natural ecological conditions. With greater intensification of activities detailed in the Polesie National Park nature conservation plan, ecological relationships in the examined area should be characterized by a great degree of naturalness.

\section{REFERENCES}

Fijałkowski D., 1960, Szata roślinna jezior Łęczyńsko-Włodawskich i otaczających je torfowisk [Plant cover of the Łęczyńsko-Włodawskie lakes and the peat bogs surrounding them; in Polish], Annales UMCS, sec. B, 14, 3.

Kondracki J., 1988, Geografia fizyczna Polski [Physical geography of Poland; in Polish], PWN, Warszawa.

Kondracki J., Richling A. 1993, Regiony fizycznogeograficzne, [Physico-geographical regions], [in:] Atlas Rzeczypospolitej Polskiej [Atlas of the Republic of Poland].

Perelman A. I., 1971, Geochemia krajobrazu [Geochemistry of landscape; in Polish], PWN, Warszawa.

Radwan S. (red.), 2002, Poleski Park Narodowy. Monografia przyrodnicza [Poleski National Park. Nature monograph; in Polish], Morpol, Lublin.

Radwan S. (Red.), 2003, Przyrodnicze podstawy ochrony i odnowy ekosystemów wodno-torfowiskowych w obszarze funkcjonalnym Poleskiego Parku Narodowego 
na tle antropogenicznych przekształceń środowiska przyrodniczego [Natural basis for conservation and renaturization of water and peat bog ecosystems in the functional area of the Poleski National Park against the background of anthropressure transformation of the natural environment, in Polish], Acta Agrophysica, 91, Instytut Agrofizyki PAN im. Dobrzańskiego, Lublin.

Radwan S., Chmielewski T.J., 1997, Ekologiczna degradacja ekosystemów wodnych Pojezierza Łęczyńsko-Włodawskiego [Ecological degradation of water ecosystems in the Łęczyńsko-Włodawski Great Lakes; in Polish]. [in:] Współczesne kierunki ekologii. Ekologia behawioralna. UMCS, Lublin, 363-370.

Radwan S., Gliński J., Geodecki M., Rozmus M. (red.), 2002a, Środowisko przyrodnicze Polesia - stan aktualny i zmiany [The natural environment of Polesie - current state and changes, in Polish], Acta Agrophysica, 66, Instytut Agrofizyki PAN im. Dobrzańskiego, Lublin

Radwan S., Gliński J., Geodecki M., Rozmus M. (red.), 2002b, Środowisko przyrodnicze Polesia - stan aktualny i zmiany [The natural environment of Polesiecurrent state and changes, in Polish], Acta Agrophysica, 67, Instytut Agrofizyki PAN im. Dobrzańskiego, Lublin.

Radwan S., Gliński J., Geodecki M., Rozmus M. (red.), 2002c, Środowisko przyrodnicze Polesia - stan aktualny i zmiany [The natural environment of Polesiecurrent state and changes; in Polish], Acta Agrophysica, 68, Instytut Agrofizyki PAN im. Dobrzańskiego, Lublin.

Richling A., 1992a, Kompleksowa geografia fizyczna [Complex physical geography; in Polish], Warszawa, PWN.

Richling A., Solon J., 2002, Ekologia krajobrazu [Landscape ecology; in Polish]. Warszawa, PWN.

Wicik B., 1997, Gleby Poleskiego Parku Narodowego. [in:] Plan Ochrony Poleskiego Parku Narodowego. Operat ochrony zasobów i walorów przyrody nieożywionej $i$ gleb [Conservation plan for Poleski National Park. Expert opinion on the resources and values of inanimate nature and soils; in Polish], Warszawa. 